\title{
OSOBITOSTI MARKETINGOVEJ KOMUNIKÁCIE V PODNIKOCH SLUŽIEB
}

\author{
Viera Frianová ${ }^{1}$
}

\section{Úvod}

Skúsenosti z praxe naznačujú, že za významný nástroj rozvoja a skvalitňovania svojich služieb môžu podniky pôsobiace $\mathrm{v}$ terciárnom sektore považovat' práve uplatňovanie marketingového prístupu vychádzajúceho z vymedzenia podstaty služieb a rešpektovania špecifík, ktoré z tejto podstaty vyplývajú. Špecifiká služieb sa v rámci marketingu služieb d’alej prezentujú voblasti vývoja potrieb, vosobitostiach výskumu trhu služieb, v marketingovej analýze služieb, v marketingových stratégiách vo sfére služieb (vrátane stratégie marketingovej komunikácie), ale aj v samotných marketingových nástrojoch (vrátane marketingovej komunikácie resp. promotion).

Akceptovanie špecifík, ktoré vyplývajú predovšetkým zo špecifík produktu, t. j. zo samotnej služby resp. balíka služieb je jedným z východiskových predpokladov úspešnej a efektívnej marketingovej komunikácie, teda takej, ktorá podniku služieb prináša žiaduce výsledky. Preto skôr, ako sa podnik začne zamýšlat' nad otázkami týkajúcimi sa prípravy, realizácie a hodnotenia procesu marketingovej komunikácie, mal by si ujasnit', aké služby v rámci svojho produktu ponúka a aké sú ich najvýznamnejšie špecifiká, ktoré by daný proces mohli výrazne ovplyvnit'.

\section{1. Špecifické prejavy služieb}

Pojem služba ako ekonomická kategória predstavuje druh produktu, ktorého podstatou je činnost' (výkon) a jeho hodnota je určená úžitkom, ktorý prináša spotrebitel'ovi ako výsledok želanej zmeny. Kotler (2006) definuje službu ako ,akúkol'vek činnost', úžitok či výhodu, ktorú môže jedna strana poskytnút' druhej, ktorá má nemateriálnu povahu a jej výsledkom nie je nadobudnutie vlastníctva. Produkcia služby môže, ale nemusí byt' spojená s hmotným produktom“ “[1].

Ekonomickú podstatu služieb možno analyzovat' prostredníctvom špecifických prejavov služieb v troch oblastiach, sú to: špecifické znaky vlastnej služby, špecifické znaky procesov poskytovania a spotreby služieb a špecifické znaky trhu služieb.

Služby majú určité špecifické znaky, ktoré ich odlišujú od klasických produktov (výrobkov) hmotnej povahy. Podl’a jednotlivých autorov sa uvádza rôzna škála znakov typických pre služby, pričom niektoré z nich možno označit' za synonymá. Najčastejšie sa uvádzajú nasledovné znaky služieb: nemateriálnost' (nehmotnost', nehmatatel'nost'),

\footnotetext{
${ }^{1}$ Ing. Viera Frianová, Katedra manažmentu, Akadémia ozbrojených síl gen. M. R. Štefánika, Liptovský Mikuláš tel. 0960423525

e-mail: frianova@aoslm.sk
} 
neskladovatel'nost', neoddelitel'nost' (simultánnost'), variabilita (rôznorodost', premenlivost' alebo individuálnost') [2]. Ako d’alšie znaky autori tiež uvádzajú: komplexnost', neopakovatel'nost' (jedinečnost'), kolektívnost', nenahraditel'nost'.

Procesy poskytovania služieb môžu mat' špecifický charakter podl'a typu služby, teda je dôležité rozlíšit', či ide o vecné alebo osobné služby. S ohl'adom na skutočnost', že samotný proces poskytovania a spotreby služieb je výrazne ovplyvnený l’udským faktorom, v marketingu služieb sa zdôrazňuje požiadavka na flexibilitu poskytovatel'a služieb, od úrovne top manažmentu až po pracovníkov priamo poskytujúcich služby. Ked’že v oblasti služieb je nízka miera anonymity poskytovatel'a služby, nároky na personál patria medzi dominujúce, čím však nemožno pripustit’ tvrdenie, že samotná služba a priestory, v ktorých sa ponúka a dodáva nemusia spíňat' vysoké nároky. Na základe uvedeného možno sumarizovat' nasledovné špecifické znaky, ktoré sa prejavujú v procesoch poskytovania a spotreby služieb [3]:

- priamy kontakt (z danej podmienky plynie potreba splnenia nasledovných predpokladov ako podmienky úspešnej realizácie služieb: pripravenost' potenciálu služby, pripravenost' objektu služby, vytvorenie predpokladov pre miestne a časové spojenie subjektu a objektu služby, miestna a časová prítomnost' v procese tvorby a spotreby služby);

- problém transportu a skladovania externého faktora (je charakteristický pre viaceré služby, a teda naň podniky musia reagovat' napr. zavedením systému rezervácie a pod.);

- problém štandardizácie služieb (z integrácie externého faktora do procesu poskytovania služieb vyplýva individualistický, personálne intenzívny, t’ažko štandardizovatel'ný charakter mnohých služieb);

- marketingová orientácia v procese produkcie služby (v protiklade k výrobe tovaru je spotrebitel' služby počas procesu jej poskytovania prítomný do tej miery, do akej on sám vystupuje ako externý faktor. Preto si poskytovatel' služby musí na jednej strane všímat' potreby dopytu po službe počas vytvárania služby, na druhej strane má osobitný význam starostlivá príprava poskytovania služieb pri priamom kontakte so zákazníkom);

- problém asymetrického rozdelenia informácií (asymetria je predstavovaná objemom informácií na strane poskytovatel'a a na strane spotrebitel'a služby. Tento častý znak služieb sa prejavuje na základe skutočnosti, že pre zákazníka sú dôležité vlastnosti služieb neznáme, nedokáže ich spozorovat' či posúdit');

- demarketing pri simultánne vykonávaných službách (produkcia a spotreba služieb sa uskutočňuje často v prítomnosti d'alších spotrebitel'ov, preto sa producent služieb musí prostredníctvom demarketingu t. j. utlmujúc dopyt, starat' o to, aby tieto vplyvy z pohl'adu kvality prekážali spotrebitel'ovi čo najmenej);

- možnost' prepojenia výrobných faktorov na územie (poskytovanie a spotreba služieb sú vel'mi často viazané na niektoré jedinečné prvky územia, napr. v cestovnom ruchu na primárnu ponuku);

- potreba kooperácie potenciálu služieb (úspešnost' poskytovania služby je vel'mi často podmienená komplexnou ponukou - ponukou balíka služieb, pričom v stredisku poskytujúcom balík služieb môže nastat' viacero situácií: v danom stredisku funguje pri danej akcii viac nezávislých poskytovatel'ov; v stredisku funguje viac subjektov, ktorí sú navzájom viac alebo menej formálne prepojení; v stredisku sú všetky služby zabezpečované jedným organizačným subjektom);

- služba sa môže v procese produkcie a spotreby modifikovat' (producent musí ku každému spotrebitel'ovi pristupovat' individuálne a reagovat' na jeho požiadavky, na zmeny vonkajších podmienok a na svoje konkrétne možnosti, pričom pôvodne 
požadovaný rozsah, kvalita a obsah služby sa môže v procese jej produkcie a spotreby niekedy aj podstatne zmenit');

- prítomnost' iných spotrebitel'ov pri hromadnom poskytovaní služieb (organizačné opatrenia musia $\mathrm{v}$ tomto smere rešpektovat' možnosti vzniku pozitívnych, ako aj negatívnych vplyvov, vyplývajúcich z tejto charakteristiky);

- špecifické nároky na pracovnú silu (i automat) poskytujúci službu (faktor priameho osobného kontaktu vytvára značný tlak na kvalifikáciu a schopnosti pracovnej sily, predovšetkým u tých pracovníkov, ktorí sú súčastou kontaktného subjektu). Poskytovanie služieb si popri vysokých nárokoch na vzdelanie často vyžaduje aj špecifické osobné vlastnosti personálu: osobitné schopnosti, osobitné zručnosti, špecifické prístupy k spotrebitelovi (ochota, úsmev a i.).

Špecifiká sféry služieb sa prejavujú aj v procese ich výmeny na trhu. Poskytnutím služby nevznikajú pre zákazníka žiadne vlastnícke práva a aj v prípade, že sa poskytne obdobná služba d'alej iným spotrebitel'om, nejde už o identickú službu. Dopyt po službách vzniká špecifickým spôsobom, predovšetkým z titulu kvalitatívnej alebo kvantitatívnej nemožnosti objektu zabezpečit' spotrebu služby samoprodukciou, prípadne tento dopyt môže byt' generovaný ekonomickými rozhodnutiami subjektu. Pre väčšinu služieb platí, že kapacita a schopnost' poskytnút' službu existuje dopredu, avšak kvalita služby je určená až procesom jej simultánnej produkcie a spotreby, pričom výsledok sa často prejaví až s časovým oneskorením. Pri procesoch produkcie a spotreby služieb sa uplatňuje významný faktor vplyvu verejnosti. Predovšetkým pri netrhových a polotrhových formách produkcie a spotreby rozhodovanie o spotrebe nadobúda podobu kolektívneho rozhodovania (verejnej vol'by) s mnohými špecifikami prejavujúcimi sa v častej uniformite poskytovaných služieb, viazanosti jedného druhu služby na iný, obmedzení prístupu k niektorým druhom služieb, obmedzení priestoru pre vlastný manažment organizácií atd'. V oblasti služieb často vznikajú špecifické výmenné vzt’ahy (napr. vzt’ahy medzi zákazníkmi a poskytovatel'mi služieb založené na báze určitého typu členstva). V niektorých odvetviach služieb (verejné služby, služby cestovného ruchu a i.) sa možno stretnút' aj súzemným princípom tvorby siete zariadení poskytujúcich služby [2].

\section{Osobitosti marketingovej komunikácie v podnikoch služieb}

Všeobecné rozhodnutie o marketingovej komunikácii zahŕňa rozhodovanie o tom, čo povedat', komu to povedat' a ako to povedat'. Tieto rozhodnutia sú obsiahnuté v stratégii marketingovej komunikácie podniku, ktorá predstavuje dôležitú súčast' celkovej marketingovej stratégie čo znamená, že ciele stratégie marketingovej komunikácie musia byt' v súlade s ciel'mi celkovej marketingovej stratégie podniku. Stratégia marketingovej komunikácie má zabezpečit', aby informácie, ktoré sprostredkováva zaujali, boli vypočuté, pochopené a v konečnom dôsledku stimulovali dopyt po službách podniku [4].

Stratégia marketingovej komunikácie, ktorú si podnik služieb vyberie pre komunikáciu s daným segmentom trhu závisí predovšetkým od:

- druhu služby,

- Štádia životného cyklu služby,

- ciel'ov komunikácie,

- identifikácie ciel’ového trhu či skupiny, na ktorý má byt' komunikácia nasmerovaná,

- charakteru konkurencie,

- výšky rozpočtu vyčleneného na marketingovú komunikáciu.

Úlohou komunikácie je prezentovat' nielen bežné vlastnosti produktu, charakter podniku či organizácie poskytujúcej služby, miesto, prípadne cenu, ale predovšetkým 
jedinečnost' služby, ktorá dáva hlavný dôvod zákazníkovi $\mathrm{k}$ tomu, aby si kúpil práve túto službu. Komunikácia by preto mala zákazníkovi službu „zhmotnit““, poskytnút' mu hmatatel'né dôkazy, čo mu pomôže, aby službu ako ponuku lepšie pochopil [3].

Rozdiely vyplývajúce z vlastností služieb, ktorými sa líšia od výrobku (najmä vysoká miera nehmotnosti služieb a vel'ké rozdiely medzi podnikmi poskytujúcimi obdobné služby) vytvárajú vyššie nároky na výber vhodného nástroja komunikácie, média i realizácie samotnej komunikovanej správy.

Podl'a Janečkovej, Vaštíkovej (2002) k osobitostiam komunikácie vo sfére služieb prispievajú aj profesijné, etické a regulačné obmedzenia (napr. legislatívne obmedzenia pri propagácii lekárskych a lekárenských služieb), obmedzenia znalostí a finančných možností manažérov hlavne malých podnikov služieb a v neposlednom rade aj podmienky trhu (existencia prirodzených monopolov v službách či lokálneho prevýšenia dopytu po službách vedie často manažment podnikov k mylnému názoru, že sa nemusia snažit' udržiavat' svoj podnik a svoje služby v povedomí zákazníkov) [5].

Pri výbere jednotlivých nástrojov, prostriedkov či foriem komunikácie musia podniky služieb predovšetkým zohl'adnit' ciel', ktorý chcú komunikáciou dosiahnut'. Vol'bu formy komunikácie (výber prostriedku) ovplyvňuje aj konkrétny druh ponúkanej služby.

Ked’že každé odvetvie služieb potrebuje vlastný marketing, musí volit' aj inú kombináciu nástrojov tvoriacich jeho komunikačný mix. Inú komunikáciu môže a musí volit' nemocnica, inú cestovná kancelária, inú banka a inú hotel. V tejto časti svojich aktivít môže podnik služieb efektívne využit' jednotlivé klasifikačné kritériá členenia služieb. Ďalším dôležitým kritériom pre výber komunikačných prostriedkov je pokrytie územia (jeho vel'kost') danou službou. Podniky služieb pôsobiace na medzinárodnej, resp. národnej úrovni (napr. medzinárodné letecké spoločnosti, investičné spoločnosti a banky) využívajú často reklamu v masovokomunikačných prostriedkoch a medzinárodných časopisoch. Miestne a regionálne pôsobiace služby (napr. taxi služba, reštaurácie a i.) využívajú okrem reklamy v regionálnej tlači, na plagátoch aj iné formy podpory (napr. osobný predaj).

Podniky služieb musia d'alej v rámci procesu marketingovej komunikácie rešpektovat' skutočnost', že niektoré služby majú reklamu zo zákona zakázanú (napr. služby daňových poradcov) alebo z etických dôvodov obmedzenú (napr. pohrebné služby).

S ohl'adom na účel, resp. funkciu komunikácie, sa možno vo sfére služieb stretnút' nielen s marketingovou komunikáciou, ktorú možno považovat' za komerčnú komunikáciu. Podniky poskytujúce platené služby za účelom dosiahnutia komerčných ciel'ov, ktoré sa odrazia v takých ukazovatel'och ako sú: predaj, zisk, obrat, tržby či zvýšenie podielu podniku na trhu, realizujú komunikáciu, ktorej možno priradit' prívlastok komerčná. Naopak, ak je ciel'om komunikácie informovat' verejnost', formovat' jej názory, hodnoty a povedomie $\mathrm{v}$ určitej oblasti, teda komunikácia nie je zameraná na priamu podporu obchodných aktivít, hovoríme o nekomerčnej komunikácii. Nekomerčná komunikácia je typická pre podniky poskytujúce služby, za ktoré neplatí priamo zákazník, teda ich financuje iný subjekt (najčastejšie štát). Špecifický charakter nadobúda komunikácia podnikov poskytujúcich verejné služby v rámci verejného sektora a na netrhovej báze. Napr. v oblasti služieb poskytovaných a často aj dotovaných štátom (polícia, požiarna ochrana, služby sociálnej starostlivosti a i.) sa reklama v pravom zmysle slova nevyužíva, aj ked' sa tu využívajú reklamné médiá (napr. rozhlas, televízia) a reklamné prostriedky (napr. spot, inzerát), ktoré svojim obsahom a ciel'om majú charakter budovania vzt'ahov s verejnost'ou.

Rozdiely vyplývajúce z vlastností jednotlivých služieb a vel'ké rozdiely medzi odvetviami, v ktorých podniky služieb pôsobia, kladú vyššie nároky na výber nástrojov $\mathrm{v}$ rámci integrovaného komunikačného mixu. $\mathrm{Za}$ jeden $\mathrm{z}$ najvhodnejších nástrojov marketingovej komunikácie sa považuje osobný predaj, ktorého význam vyplýva predovšetkým z neoddelitel'nosti služieb, t. j. osobnej interakcie medzi poskytovatel'om 
služieb a zákazníkom. V tejto forme komunikácie vyvíja hlavnú aktivitu podnik, ale nepriamo aj spokojní zákazníci, ktorí svoju dobrú skúsenost' so službou prezentujú v okruhu svojich známych. Ďalšou efektívnou zložkou komunikácie sú pracovníci, na ktorých podnik pôsobí najmä prostredníctvom interného PR a oni zas pôsobia cez interaktívny marketing na zákazníkov.

Payne (1996) uvádza, že osobný predaj má v porovnaní s ostatnými prvkami komunikačného mixu v službách nasledovné výhody [6]:

- Osobný kontakt so zákazníkom. Kontakt so zákazníkom plní tri funkcie, ide o predaj, službu zákazníkovi a monitorovanie.

- Posilnenie vzt'ahov so zákazníkmi a budovanie lojality.

- Stimulácia nákupu d'alších služieb, poskytovaných daným podnikom (cross-selling). Pre dosiahnutie úspechu osobného predaja služieb odborníci odporúčajú využit' nasledovný model:

- Riadit' (harmonizovat') stretnutie so zákazníkom pri nákupe služieb (vyvolat' jeho potreby a identifikovat' jeho priania a očakávania, využitím odbornej kvalifikácie a schopnosti prezentácie služby získat' jeho pozitívnu spoluúčast' a zanechat' v ňom príjemný, dlhotrvajúci uspokojivý zážitok z nákupu služby).

- Ul'ahčit' zákazníkovi hodnotenie kvality služby zavedením štandardov očakávaného výkonu (očakávania zákazníka využit' ako základňu pre posúdenie kvality).

- Zviditel'nit' (zhmotnit') službu tým, že predajca pomôže zákazníkovi pochopit' hodnotiace kritériá, vytvorí podmienky pre možnost' porovnania alternatív služieb, poukáže na výhody svojej ponuky a vysvetlí zákazníkovi jedinečnost' služby (diferenčnú výhodu).

- Zdôraznit' image podniku tým, že informuje zákazníka o vlastnostiach služby a poslaní podniku.

- Využit' referencie z externých zdrojov, zapojit' do komunikačného procesu skúsených zákazníkov a umožnit’ im, aby boli vtiahnutí do tzv. ústnej reklamy. Rozvíjat' a riadit' priaznivú publicitu podniku.

- Pochopit' a uznávat' význam zapojenia zákazníka do vytvorenia koncepcie služby. Využívat' stretnutia so zákazníkmi na špecifikovanie vlastností služieb, zlepšovanie kvality ponuky. Testovat' návrhy nových služieb [7].

Mnohé služby sa účinne predávajú s pomocou výhier, sút’aží, bezplatného odberu služby a pod., teda prostredníctvom aktivít podpory predaja. Podpora predaja je v podnikoch služieb vel'mi výrazne orientovaná nielen na zákazníka ale aj na predajný personál. Ide napr. o stimuláciu predajcov prostredníctvom odmien, vecných a spoločenských ocenení, sút'aží a pod. a stimuláciu sprostredkovatel'ov služieb prostredníctvom zliav, odmien, umožnenia ich účasti na výstavách, vel'trhoch atd'. Aj ked' podpora predaja má všeobecne krátkodobú, taktickú, na okamžitý efekt zameranú podstatu, všetky jej akcie by mali byt' súčast'ou väčšej a dlhodobejšej stratégie. To znamená, že v súčasnosti sa čoraz častejšie zdôrazňuje, že súčast'ou podpory predaja sú aj prvky, ktoré efektívne prispievajú k budovaniu dlhodobého vzt’ahu so zákazníkom (napr. vernostné programy, výhody plynúce z členských kariet klubový predaj a i.).

Rozšírit' vedomosti zákazníka o službe a presvedčit' ho o výhodnosti nákupu služby umožňuje podnikom služieb už spomínaná reklama, pričom v sektore služieb sa zdôrazňuje najmä význam ústnej reklamy, ktorej šíritel’mi sú spokojní zákazníci.

Marketingová komunikácia realizovaná prostredníctvom nástrojov budovania vzt’ahov $\mathrm{s}$ verejnost'ou (PR) má v porovnaní s predchádzajúcimi nástrojmi trochu iné zameranie, ktoré spočíva predovšetkým $\mathrm{v}$ inej, resp. širšej ciel'ovej skupine tejto formy komunikácie a v ciel'och a prostriedkoch, ktoré na dosahovanie ciel'ov využíva. Kým podpora predaja služieb zahŕňa skôr krátkodobé aktivity zamerané predovšetkým na zvýšenie predaja, podstatou PR 
sú naopak snahy o dlhodobé ovplyvnenie pocitov, názorov a presvedčenia spotrebitel'ov, ktoré sa premietajú do takých ciel'ov ako je tvorba dobrého mena (goodwill) a predstavy (image), posilnenie pozície podniku a jeho značky (brand, logo) na trhu [8]. PR teda treba chápat' ako dlhodobý, plánovitý, tvorivý a systematický proces. Skúsenosti z každodennej praxe podnikov dokazujú, že ani tie najlepšie aktivity PR nezvládnu komunikáciu so silne negatívne naladenou verejnost'ou, predaj nekvalitných služieb, nahradzovanie dobrých činov, zlepšovanie image zlého podniku a pod. Na druhej strane sa zdôrazňuje ich osobitný význam v krízovej situácii, v ktorej sa podnik služieb môže ocitnút'.

Ďalším nástrojom využívaným $v$ rámci komunikačného mixu je aj priamy (direct) marketing. V súčasnosti je priamy marketing považovaný za interaktívny systém propagácie založený na priamom kontakte podniku so svojimi jasne zadefinovanými zákazníkmi [4]. Jeho hlavnou výhodou je budovanie dlhodobejších užších vzt’ahov medzi klientom a podnikom, ktoré vyúst'ujú do detailného poznania spotrebitel'ských potrieb a následného okamžitého prispôsobovania ponuky služieb. Počas svojej existencie sa priamy marketing rozvinul do mnohých foriem, medzi jeho nástroje a médiá využívané podnikmi služieb možno zaradit': priamu poštovú zásielku (direct e-mail), katalógy, reklamné e-maily a sms správy, interaktívnu televíziu, roznášanie letákov do schránok (door-to door advertisement), využívanie nových interaktívnych médií (ako napr. Internet, webové stránky, CD-ROM a iné).

V prípade, že sú zákazníci pripojení k Internetu, má pre podniky služieb význam vytvárat' systém služieb zákazníkom na Internete. Internet predstavuje bezkonkurenčný nástroj komunikácie v prípade služieb, ktoré majú vo väčšej miere nehmotný charakter (software, analýzy, štúdie, projekty, vzorky zvukových a obrazových záznamov), ktoré možno prostredníctvom Internetu nielen ponúkat' a predávat', ale dokonca aj distribuovat'. V prípade využitia Internetu možno oproti klasickým nástrojom komunikácie previest' potenciálneho zákazníka celým komunikačným procesom plynule a bez prerušenia. Jednotlivé fázy presvedčovacieho procesu - od prvotného oslovenia potenciálneho zákazníka animovanými reklamnými pruhmi v komerčných internetových médiách cez poskytnutie bližších informácií nenásilnou a zábavnou formou (napr. sút’aže o ceny) až po získanie objednávky prostredníctvom prezentovaného formulára a následnú podporu zákazníka $v$ rámci moderovaných diskusných fór zákazníckych komunít - môžu byt' z pohl'adu zákazníka oddelené stlačením tlačidla počítačovej myši [5].

V podnikoch služieb sa zdôrazňuje požiadavka, aby bol ponúkaný produkt podniku „šitý na mieru“ s ohl'adom na charakter podnikania a individuálne potreby klienta, čo v praxi znamená, že ponuka podnikov služieb často pozostáva z celého balíka služieb napr. (ponuka bankových služieb, služieb mobilných operátorov, služieb cestovného ruchu a i.). Z uvedeného vyplýva, že medzi produkty podnikov služieb zarad’ujeme i zostavovanie komplexných balíkov služieb (z angl. packaging), ich programové zameranie (programming) a l'udský faktor [9].

Packaging predstavuje marketingovú techniku, ktorej ciel’om je zostavenie balíka služieb. Ide o spojenie súvisiacich a vzájomne sa doplńajúcich služieb (napr. ubytovacích, stravovacích, doplnkových a pod.) do komplexného produktu, ponúkaného za jednotnú cenu (napr. zájazd z ponuky cestovnej kancelárie).

Programming zahŕňa špecializované činnosti, programy alebo udalosti, ktoré majú zvýšit' prít'ažlivost' celého balíka alebo jednotlivej služby podniku v očiach zákazníka, a tak prispiet' k zvýšeniu ich spotreby. Predpokladom úspechu programmingu je skutočnost', že „package“ ponúka jednak výhody pre zákazníkov - úsporu času, úsilia, cenovú výhodnost', lepšie plánovanie výdavkov, ako aj výhody pre zainteresované podniky služieb - tvorba produktu pre rôzne ciel'ové skupiny, zvýšenie dopytu v období mimo hlavnej sezóny atd'. 
Pri predaji produktu podniku služieb zohráva dôležitú úlohu l'udský faktor, teda najmä tí pracovníci, ktorí prichádzajú do priameho kontaktu so zákazníkmi (tzv. kontaktný personál). Ich vystupovanie a správanie môže ovplyvnit' celkový dojem zákazníka z poskytnutej služby, môže umocnit', ale tiež zničit' jeho zážitok. Preto jednou z primárnych požiadaviek podnikov pôsobiacich $\mathrm{v}$ terciárnom sektore je zamestnávanie kvalitného a odborne zdatného personálu.

Ak je produktom podniku komplexný balík služieb, v rámci procesu marketingovej komunikácie potom hovoríme o propagácii balíka služieb. Kotler (2006) vymedzuje propagáciu balíka služieb ako formu komunikácie, ktorá predstavuje firemný oznam určený k posilneniu povedomia o službách, k vyvolaniu záujmu o ne a k motivácii ku ich kúpe [1].

V rámci propagácie balíkov služieb podnik využíva všetky dostupné formy a nástroje, ktoré sa vzájomne doplńajú a podporujú v záujme dosiahnutia čo najväčšieho synergického efektu propagačného mixu. Pričom propagačné aktivity musia byt' koordinované a musia byt' integrálnou súčast’ou d'alších nástrojov marketingovej komunikácie. Formy a nástroje propagácie by mali mat' masový, interpersonálny a interdisciplinárny charakter. Z masových foriem propagácie podniky služieb najčastejšie využívajú reklamu, prácu s verejnost'ou a podporu predaja. Interpersonálnu propagáciu im umožňuje predovšetkým osobný predaj a elektronická propagácia. Uvedené aktivity sú previazané s priamym marketingom a programami budovania lojálnosti zákazníkov (vernostné programy) - táto propagácia sa vzhl'adom na prvok vytvárania väzieb na zákazníka nazýva aj vzt'ahová propagácia [10].

Pri tvorbe komunikačného mixu podnikov služieb sa v súčasnosti stále častejšie možno stretnút' s úvahami o možnosti štandardizácie jeho jednotlivých nástrojov. Východiskom štandardizácie jednotlivých prvkov komunikačného mixu je presvedčenie, že zákazníci sú si podobní (rovnakí) všade vo svete, podobnosti medzi zákazníkmi prevyšujú rozdiely medzi nimi a že dobrá služba má univerzálny aspekt. V rámci úvah o štandardizácii v oblasti komunikačnej politiky sa pozornost' obracia predovšetkým na štandardizáciu reklamy a podpory predaja. Štandardizácia reklamy umožňuje využit' synergické výhody plynúce z prekrývania priestoru a pôsobenia medzinárodných médií, vedie tiež k svetovo konzistentnej profilácii služby, a tým k jednoznačnému vymedzeniu vo vzt’ahu ku konkurencii. Štandardizácia podpory predaja služieb závisí od rozdielnych možností podl'a špecifík krajín a od postojov predajcov služieb k spoločnej podpore predaja [11].

\section{Záver}

V súčasnosti patrí sféra služieb medzi najdynamickejšie sa rozvíjajúce oblasti ekonomiky, pričom uplatňovanie marketingového prístupu vychádzajúceho z vymedzenia podstaty služieb a rešpektovania ich špecifík možno považovat' za významný nástroj nielen rozvoja ale aj skvalitňovania tejto sféry.

Priblíżit' nehmotný produkt spotrebitel'ovi - teda „zhmotnit“، ponúkanú službu zákazníkovi, poskytnút' mu hmatatel'né dôkazy za účelom lepšieho pochopenia služby ako ponuky, a tým znížit' neistotu zákazníkov pri jej výbere a kúpe, umožňuje podnikom práve realizácia efektívnej a účinnej marketingovej komunikácie založenej na uplatňovaní konkrétnej stratégie marketingovej komunikácie využívajúcej rôzne nástroje v rámci integrovaného komunikačného mixu.

$\mathrm{V}$ dôsledku neoddelitel'nosti služby od jej producenta sa v rámci komunikačného mixu spomedzi všetkých nástrojov marketingovej komunikácie v podnikoch služieb zdôrazňuje úloha osobného predaja a ústnej reklamy. Poznatky z praxe ukazujú, že tradičné nástroje komunikačného mixu, sú v súčasnosti efektívne dopĺňané modernými formami priameho marketingu a internetovej komunikácie.

Ked’že práve marketingová komunikácia umožňuje zvýšit' výkonnost' služieb a prezentovat' okrem bežných vlastností služieb predovšetkým ich jedinečnost', ktorá je pre 
zákazníkov hlavným dôvodom pre kúpu služieb, môže pre podnik predstavovat' zdroj jedinečnej konkurenčnej výhody. Práve uvedená skutočnost' zdôrazňuje potrebu venovat' danej problematike zvýšenú pozornost' ako zo strany odbornej verejnosti, tak aj zo strany manažmentu každého podniku služieb.

\section{Literatúra}

[1] KOTLER, P.: Marketing management. Prentice Hall: Pearson 2006, ISBN 0-13-145757-8

[2] MATEIDES, A. - ĎAĎO, J.: Služby. Bratislava: Miroslav Mračko 2002, ISBN 80-8057452-9

[3] ĎAĎO, J. - PETROVIČOVÁ, J. - KOSTKOVÁ, M.: Marketing služieb. Bratislava: Epos 2006, ISBN 80-8057-662-9-296

[4] MAJTÁN, Š. a kol.: Odbytová stratégia. Bratislava: Ekonóm 2007, ISBN 978-80225-2252-6

[5] JANEČKOVÁ, L. - VAŠTÍKOVÁ, M.: Marketing služieb. Praha: Grada Publishing 2000, ISBN 80-7169-995-0

[6] PAYNE, A.: Marketing služeb. Praha: Grada Publishing 1996, ISBN 80-7169-276-X

[7] STAFFORD, M. R.: Promotion of services: Journal of Services Marketing, 16, 2002, Nr. 5, ISSN 0887-6045

[8] KITA, J.: Marketing. Bratislava: Ekonóm 2000, ISBN 80-887-1570-9

[9] PAULIČKOVÁ, A. - PAULIČKOVÁ, R.: Spolupráca verejného a súkromného sektora na trhu cestovného ruchu v Slovenskej republike. In: Zborník z medzinárodnej konferencie „New Members - New Challenges for the European Regional Development Policy“. Nový Smokovec, s. 278-284, ISBN 80-225-2060-8

[10] STASZEWSKA, J.: Zdokonal'ovanie propagácie balíkov služieb v cestovnom ruchu. Ekonomická revue cestovného ruchu, 4, 2007, č. 2, s. 103-107, ISSN 0139-8660

[11] ČIHOVSKÁ, V. - KITA, J.: Nové paradigmy marketingu v procese globalizácie trhov. Ekonomický časopis. 53, 2005, č. 6, s. 611-625, ISSN 0013-3035

\section{Grantová podpora}

Príspevok je súčast'ou riešenia projektu VEGA č. 1/4579/07 „Diagnostikovanie hodnotových vzt’ahov a trhových aktivít v podniku“ na Fakulte podnikového manažmentu Ekonomickej univerzity v Bratislave. 